\title{
PENGHITUNGAN CADANGAN PREMI TAHUNAN PADA ASURANSI JIWA SEUMUR HIDUP DENGAN MENGGUNAKAN METODE FACKLER
}

\author{
ANGGRITA JANUARTI, RIRI LESTARI, AHMAD IQBAL BAQI \\ Program Studi Matematika, \\ Fakultas Matematika dan Ilmu Pengetahuan Alam, Universitas Andalas, \\ Kampus UNAND Limau Manis Padang, Indonesia, \\ anggrita0114@yahoo.co.id
}

\begin{abstract}
Abstrak. Usaha perasuransian mempunyai beberapa kemungkinan resiko yang akan ditanggung oleh pihak perusahaan asuransi. Salah satu resikonya adalah klaim dari pihak pemegang polis atas kematian yang mengharuskan perusahaan membayarkan uang pertanggungan sesuai kontrak asuransi, dan resiko biaya-biaya yang diperlukan selama asuransi berlaku. Dengan adanya kemungkinan resiko tersebut, maka perusahaan asuransi membutuhkan dana cadangan untuk membayarkan uang pertanggungan dan memenuhi biaya-biaya tersebut. Penelitian ini bertujuan untuk menghitung cadangan premi tahunan pada asuransi jiwa seumur hidup. Adapun metode yang digunakan adalah metode Fackler yang merupakan metode untuk menghitung cadangan retrospektif. Dalam penelitian ini diberikan ilustrasi kasus. Langkah-langkahnya adalah dengan menghitung nilai anuitas awal, premi tunggal bersih, premi tahunan bersih, menghitung masing-masing biaya, menghitung besarnya premi kotor tahunan, dan menghitung besar cadangan premi di akhir tahun ke-t. Dengan menggunakan cadangan premi di akhir tahun ke- $t$ maka dapat dihitung cadangan premi di akhir tahun ke- $t+1$, sehingga besarnya cadangan premi tahunan asuransi jiwa seumur akan bertambah setiap tahunnya.

Kata Kunci: Anuitas, premi kotor, cadangan premi, cadangan retrospektif, metode Fackler
\end{abstract}

\section{Pendahuluan}

Seiring perkembangan zaman yang semakin pesat, kebutuhan manusiapun semakin kompleks. Usaha untuk mendapatkan perlindungan finansial juga akan meningkat sehingga semakin banyak pula perusahaan asuransi yang menawarkan jasanya. Sejumlah premi akan dibayarkan jika seseorang mengikuti suatu asuransi sesuai dengan ketentuan yang telah disepakati. Premi yang dibayarkan ini adalah premi kotor (gross premi) yang merupakan gabungan dari premi bersih dan biaya-biaya atau dengan kata lain premi kotor ini adalah gambaran jumlah biaya yang akan dibutuhkan oleh perusahaan asuransi. Dengan adanya kewajiban perusahaan asuransi mengeluarkan sejumlah uang selama asuransi berlangsung dan pada saat terjadinya klaim maka asuransi membutuhkan adanya dana cadangan sehingga perusahaan tidak akan mengalami kerugian. Pada asuransi jiwa seumur hidup, cadangan premi dapat dihitung dengan menggunakan metode Fackler. 
2 Anggrita Januarti dkk.

\section{Hasil dan Pembahasan}

Simbol-simbol komutasi yang digunakan untuk menentukan premi kotor dan cadangan premi asuransi terdiri dari

$$
\begin{aligned}
& D_{x}=v^{x} l_{x} \\
& N_{x}=D_{x}+D_{x+1}+\cdots+D_{\omega} \text { sehingga } N_{x+n}=D_{x+n}+D_{x+n+1}+\cdots+D_{\omega} \\
& C_{x}=v^{x+1} d_{x} \\
& M_{x}=C_{x}+C_{x+1}+\cdots+C_{\omega} \text { sehingga } M_{x+n}=C_{x+n}+C_{x+n+1}+\cdots+C_{\omega} \\
& \ddot{a}_{x}=\frac{N_{x}}{D_{x}} \quad \ddot{a}_{x: \bar{n} \mid}=\frac{N_{x}-N_{x+n}}{D_{x}} \\
& A_{x}=\frac{M_{x}}{D_{x}} \quad A_{x: \bar{n} \mid}^{1}=\frac{M_{x}-M_{x+n}}{D_{x}} \\
& A_{x: \bar{n} \mid}=\frac{M_{x}-M_{x+n}+D_{x+n}}{D_{x}}
\end{aligned}
$$

dengan indeks $\omega$ menyatakan usia tertinggi yang dapat dicapai pada tabel mortalita.

\subsection{Menentukan Premi Kotor Asuransi Jiwa Seumur Hidup}

Premi kotor asuransi jiwa seumur hidup dapat dinotasikan dengan $P_{x}^{*}$ dengan $x$ merupakan umur pemegang polis pada saat pembelian polis. Premi kotor ini dirumuskan dengan

$$
\begin{aligned}
P_{x}^{*} \ddot{a}_{x} & =A_{x}+\alpha+\beta P_{x}^{*} \ddot{a}_{x}+\gamma \ddot{a}_{x} \\
P_{x}^{*} & =\frac{A_{x}+\alpha+\beta P_{x}^{*} \ddot{a}_{x}+\gamma \ddot{a}_{x}}{\ddot{a}_{x}} \\
P_{x}^{*}-\frac{\beta P_{x}^{*} \ddot{a}_{x}}{\ddot{a}_{x}} & =\frac{A_{x}+\alpha+\gamma \ddot{a}_{x}}{\ddot{a}_{x}} \\
P_{x}^{*}(1-\beta) & =\frac{A_{x}}{\ddot{a}_{x}}+\frac{\alpha}{\ddot{a}_{x}}+\gamma \\
P_{x}^{*} & =\frac{1}{(1-\beta)}\left\{\frac{A_{x}}{\ddot{a}_{x}}+\frac{\alpha}{\ddot{a}_{x}}+\gamma\right\} \\
P_{x}^{*} & =\frac{1}{(1-\beta)}\left\{P_{x}+\frac{\alpha}{\ddot{a}_{x}}+\gamma\right\}
\end{aligned}
$$

\subsection{Metode Fackler}

Metode Fackler adalah turunan dari rumus cadangan retrospektif yang merupakan penghitungan cadangan premi berdasarkan premi dan biaya pada waktu yang telah lalu. Bentuk umum cadangan retrospektif adalah

$$
{ }_{t} V=P_{t} U_{x}-{ }_{t} k_{x}
$$

dengan ${ }_{t} V$ menyatakan cadangan premi di akhir tahun ke- $t, P$ menyatakan premi bersih tahunan, ${ }_{t} U_{x}$ menyatakan dana tonti (forborne annuity), ${ }_{t} k_{x}$ menyatakan 
dana akumulasi asuransi, $t$ menyatakan periode, dan $x$ menyatakan umur pemegang polis.

Pada penelitian ini akan dihitung cadangan premi yang ditentukan dengan menggunakan premi kotor, sehingga notasi $P$ diganti dengan $P_{x}^{*}$. Maka persamaan $(2.4)$ menjadi

$$
{ }_{t} V=P_{x}^{*}{ }_{t} U_{x}-{ }_{t} k_{x}
$$

Persamaan Fackler dapat ditentukan dengan mensubstitusikan persamaan ${ }_{t} U_{x}=$ $\frac{N_{x}-N_{x+t}}{D_{x+t}}$ dan ${ }_{t} k_{x}=\frac{M_{x}-M_{x+t}}{D_{x+t}}$ pada persamaan retrospektif $(2.5)$

$$
{ }_{t} V=P_{x}^{*} \frac{N_{x}-N_{x+t}}{D_{x+t}}-\frac{M_{x}-M_{x+t}}{D_{x+t}}
$$

Kemudian substitusikan persamaan (2.1) ke persamaan (2.6)

$$
{ }_{t} V=P_{x}^{*} \frac{N_{x}-N_{x+t-1}}{D_{x+t-1}} \cdot \frac{D_{x+t-1}}{D_{x+t}}-\frac{M_{x}-M_{x+t-1}}{D_{x+t-1}} \cdot \frac{D_{x+t-1}}{D_{x+t}}+P_{x}^{*} \frac{D_{x+t-1}}{D_{x+t}}-\frac{C_{x+t-1}}{D_{x+t}}
$$

Substitusikan $U_{x+t-1}=\frac{D_{x+t-1}}{D_{x+t}}$ dan $k_{x+t-1}=\frac{C_{x+t-1}}{D_{x+t}}$ pada persamaan $(2.7)$, sehingga diperoleh

$$
{ }_{t} V=\left({ }_{t-1} V+P_{x}^{*}\right) \frac{D_{x+t-1}}{D_{x+t}}-\frac{C_{x+t-1}}{D_{x+t}}
$$

kemudian substitusikan $D_{x+t-1}=V^{x+t-1} l_{x+t-1}$ dan $C_{x+t-1}=v^{x+t} d_{x+t-1}$ pada persamaan (2.8), sehingga diperoleh

$$
{ }_{t} V=\frac{\left(l_{x+t-1 \cdot t-1} V+l_{x+t-1} P_{x}^{*}\right)(1+i)-d_{x+t-1}}{l_{x+t}}
$$

Diperoleh bahwa rumus Fackler untuk menentukan nilai cadangan premi di akhir tahun ke-t dengan menggunakan premi kotor tahunan untuk menentukan besar cadangan asuransi jiwa adalah

$$
{ }_{t} V=\frac{\left(l_{x+t-1 \cdot t-1} V+l_{x+t-1} P_{x}^{*}\right)(1+i)-d_{x+t-1}}{l_{x+t}}
$$

sedangkan rumus Fackler untuk menentukan nilai cadangan premi tahunan asuransi jiwa di akhir tahun ke- $t+1$ dapat ditentukan dengan

$$
{ }_{t+1} V=\frac{\left(l_{x+t}\left({ }_{t} V\right)+l_{x+t} P_{x}^{*}\right)(1+i)-d_{x+t}}{l_{x+t+1}}
$$

Dengan memasukkan persamaan $v^{-1}=(1+i)$, sehingga diperoleh

$$
{ }_{t+1} V=\frac{v^{x+t} l_{x+t}\left({ }_{t} V+P_{x}^{*}\right)}{v^{x+t+1} l_{x+t+1}}-\frac{v^{x+t+1} d_{x+t}}{v^{x+t+1} l_{x+t+1}}
$$

substitusikan $D_{x+t}=v^{x+t} l_{x+t}$ dan $C_{x+t}=v^{x+t+1} d_{x+t}$ sehingga

$$
{ }_{t+1} V=\left({ }_{t} V+P_{x}^{*}\right) \frac{D_{x+t}}{D_{x+t+1}}-\frac{C_{x+t}}{D_{x+t+1}}
$$


substitusikan $U_{x+t}=\frac{D_{x+t}}{D_{x+t+1}}$ dan $k_{x+t}=\frac{C_{x+t}}{D_{x+t}}$, sehingga diperoleh rumus Fackler untuk menentukan nilai cadangan premi tahunan asuransi jiwa seumur hidup di akhir tahun ke- $t+1$ adalah

$$
{ }_{t+1} V=\left({ }_{t} V+P_{x}^{*}\right) U_{x+t}-k_{x+t}
$$

\subsection{Ilustrasi Kasus}

Pak Amran yang berumur 40 tahun mengikuti asuransi jiwa seumur hidup dengan mengharapkan uang pertanggungan yang akan diterima oleh ahli warisnya kelak sebesar Rp. 175.000.000,-- Tingkat suku bunga asuransi ini adalah 2,5\% pertahun. Dan selama asuransi berjalan terdapat biaya-biaya yang dibutuhkan, yang terdiri dari:

a) Biaya penutupan baru dan rekruitmen:

1) Biaya administrasi untuk penutupan baru polis baru sebesar 0,16\% dari uang pertanggungan

2) Komisi agen $12 \%$ dari premi bersih

b) Biaya pengumpulan premi sebesar 4,5\% dari premi kotor

c) Biaya pemeliharaan sebesar $0,4 \%$ dari besarnya uang pertanggungan

Berdasarkan ilustrasi diatas, maka terdapat beberapa notasi yang digunakan, yaitu:

- Usia tertanggung, misalkan $x=40$ tahun

- Tingkat suku bunga, misalkan $i=2.5 \%$

- Uang Pertanggungan, Rp. 175.000.000,-

- Biaya administrasi, misalkan $\alpha_{1}=0,16 \%$ dari uang pertanggungan

- Komisi agen, misalkan $\alpha_{2}=12 \%$ dari premi bersih tahunan

- Biaya penutupan baru dan rekruitment, misalkan $\alpha=\alpha_{1}+\alpha_{2}$

- Biaya pengumpulan premi, misalkan $\beta=4,5 \%$ dari premi kotor

- Biaya pemeliharaan, misalkan $\gamma=0,4 \%$ dari uang pertanggungan

Tabel Mortalita CSO 1941 untuk mendapatkan nilai simbol komutasi yang dibutuhkan dalam menghitung nilai cadangan premi tahunan asuransi seumur hidup yang diikuti oleh Pak Amran

$$
\begin{aligned}
D_{40} & =328.983,61 & N_{40} & =6.708 .572,65 \\
M_{40} & =165.359,8889 & C_{40} & =1.983,511 \\
\ddot{a}_{40} & =20,39181 & U_{40} & =1,0313738 \\
k_{40} & =6,21837 & &
\end{aligned}
$$

Dari nilai-nilai simbol komutasi yang diperoleh dari tabel, maka dapat dihitung

a) Premi tunggal bersih $=R p .87 .961 .770,-$

b) Premi tahunan bersih $=R p .4 .313 .582,-$

c) Penghitungan biaya penutupan baru dan rekruitment dengan:

- Biaya administrasi $\left(\alpha_{1}\right)=R p .2 .800 .000,-$ 
- Komisi agen $\left(\alpha_{2}\right)=R p .517 .630,-$

maka besar biaya penutupan baru dan rekruitment adalah $=R p .3 .317 .630,-$

d) Penghitungan biaya pemeliharaan $=R p .700 .000,-$

e) Penghitungan premi kotor tahunan yang akan dibayarkan dinotasikan de-ngan $P_{x}^{*}=R p .5 .420 .185,-$

f) Cadangan premi tahunan untuk nilai $t=0$ adalah $R p \cdot 5.590 .230,-$

Maka cadangan diakhir tahun ke- $t+1$ dapat dilihat pada tabel berikut.

Tabel 1. Nilai Cadangan Premi Tahunan Akhir Tahun $t+1$ Pada Asuransi Jiwa Seumur Hidup Pembayaran Premi Setiap Tahun Menggunakan Tabel CSO 1941

\begin{tabular}{|c|c|c|c|}
\hline $\mathrm{t}$ & $U_{40+t}$ & $k_{40+t}$ & $t+1 V\left(P_{40}^{*}\right)$ \\
\hline 0 & 1,0313738 & 00621837 & Rp.5.590.237,- \\
\hline 1 & 1,0317993 & 0,00663343 & Rp.11.360.545,- \\
\hline 2 & 1,0322569 & 0,00707995 & Rp.17.322.025,- \\
\hline 3 & 1,0327555 & 0,00756634 & Rp.23.487.142,- \\
\hline 4 & 1,0333077 & 0,00810506 & Rp.29.870.163,- \\
\hline 5 & 1,0339013 & 0,00868419 & Rp.36.486.737,- \\
\hline 6 & 1,0345485 & 0,00931559 & Rp.43.354.743,- \\
\hline 7 & 1,0352597 & 0,01000948 & Rp.50.494.717,- \\
\hline 8 & 1,0360236 & 0,01075471 & Rp.57.929.158,- \\
\hline 9 & 1,0368717 & 0,01158219 & Rp.65.685.141,- \\
\hline 10 & 1,0377851 & 0,01237331 & Rp.73.792.048,- \\
\hline 11 & 1,0387846 & 0,01344836 & Rp.82.284.448,- \\
\hline 12 & 1,0398701 & 0,01450741 & Rp.91.201.425,- \\
\hline 13 & 1,0410640 & 0,01567224 & Rp.100.589.280,- \\
\hline 14 & 1,0423553 & 0,01693205 & Rp.110.499.527,- \\
\hline 15 & 1,0437665 & 0,01830871 & Rp.120.993.112,- \\
\hline 16 & 1,0453097 & 0,01981436 & Rp.132.141.046,- \\
\hline 17 & 1,0469866 & 0,02145037 & Rp.144.024.765,- \\
\hline 18 & 1,0488193 & 0,02323834 & Rp.156.740.748,- \\
\hline 19 & 1,0508181 & 0,02518845 & Rp.170.401.643,- \\
\hline 20 & 1,0529994 & 0,2731645 & Rp.185.140.280,- \\
\hline 21 & 1,0553744 & 0,02963351 & Rp.201.112.636,- \\
\hline 22 & 1,0579881 & 0,0321836 & Rp.218.509.267,- \\
\hline 23 & 1,0608138 & 0,03494025 & Rp.237.547.452,- \\
\hline 24 & 1,0639190 & 0,03796969 & Rp.258.497.886,- \\
\hline 25 & 1,0673076 & 0,04127573 & Rp.281.681.762,- \\
\hline
\end{tabular}

\section{Kesimpulan}

Penentuan nilai cadangan premi pada asuransi jiwa seumur hidup, asuransi jiwa berjangka, dan asuransi jiwa dwiguna dengan menggunakan metode Fackler dapat digunakan langkah-langkah berikut, yaitu

1) Menentukan present value anuitas awal masing-masing asuransi

2) Menentukan premi tunggal masing-masing asuransi 
6 Anggrita Januarti dkk.

3) Menentukan premi tahunan bersih masing-masing asuransi

4) Menentukan biaya-biaya (loading)

5) Menentukan premi kotor

6) Menentukan dana tonti (foreborn annuity)

7) Menentukan biaya pertanggungan

8) Menentukan cadangan premi tahunan asuransi jiwa seumur hidup akhir tahun ke- $t+1$ dengan menggunakan rumus

$$
{ }_{t+1} V\left(P_{x}^{*}\right)=\left({ }_{t} V+P_{x}^{*}\right) U_{x+t}-k_{x+t}
$$

\section{Ucapan Terima kasih}

Penulis mengucapkan terima kasih kepada Ibu Hazmira Yozza, M.Si, Bapak Dr. Dodi Devianto dan Ibu Dr. Lyra Yulianti yang telah memberikan masukan dan saran sehingga jurnal ini dapat diselesaikan dengan baik.

\section{Daftar Pustaka}

[1] Bain, Lee J dan Max Engelhardt. (1991). Introduction to Probability and Mathematical Statistics. California: Duxbury Press.

[2] Bowers, N.L., H.U. Gerber, D.A. Jones, dan C.J. Nesbitt. 1997. Actuarial Mathematics Second Edition. Illinois: The Society of Actuaries.

[3] Futami, Takashi. 1993. Matematika Asuransi Jiwa Bagian I. Tokyo: Incorporated Foundation Oriental Life Insurance Cultural Development Center.

[4] Futami, Takashi. 1994. Matematika Asuransi Jiwa Bagian II. Tokyo: Incorporated Foundation Oriental Life Insurance Cultural Development Center.

[5] Jordan Jr, C. W. 1991. Society of Actuaries' Textbook on Life Contingencies, Second Edition. Chicago: The Society of Actuaries.

[6] Larson R.E. dan E.A. Gaumnitz. 1951. Life Insurance Mathematics. New York: John Wiley and Sons, Inc.

[7] Sembiring, R.K. 1986. Buku Materi Pokok Asuransi I. Jakarta: Karunika, Universitas Terbuka.

[8] Undang-Undang Republik Indonesia Tahun 1992 tentang Usaha Perasuransian. 1992. Jakarta: Armas Duta Jaya. 